\title{
Analisis Ketersediaan Air Meteorologis Untuk Memenuhi Kebutuhan Air Domestik Penduduk Di Kabupaten Malang
}

\author{
Maula Zakiyyatul Millah ${ }^{1}$ \\ ${ }^{1}$ Program Studi Pendidikan Geografi, Universitas Kanjuruhan Malang, Malang 65148, Indonesia \\ Email : maulazakiyah@gmail.com
}

Dikirim : 18 Maret 2019

Diterima: 30 Maret 2019

\begin{abstract}
Abstrak Kabupaten Malang merupakan salah satu kabupaten yang terletak di Provinsi Jawa Timur. Perkembangan suatu wilayah akan menyebabkan kebutuhan air terus meningkat seiring dengan bertambahnya jumlah penduduk. Persebaran curah hujan yang tidak merata akibat dari keragaman kondisi fisiografis Kabupaten Malang juga menyebabkan ketersediaan air disetiap wilayah berbeda. Metode yang digunakan dalam penelitian adalah metode deskriptif dengan menggunakan pendekatan kuantitatif. Sampel wilayah yang digunakan dalam penelitian ini adalah tujuh kecamatan yang ada di Kabupaten Malang, yaitu Kecamatan Kalipare, Kecamatan Donomulyo, Kecamatan Pagak, Kecamatan Sumbermanjing Wetan, Kecamatan Jabung, Kecamatan Singosari, dan Kecamatan Lawang. Tujuan penelitian ini adalah menganalisis ketersediaan air meteorologis dan mengalisis kebutuhan air domestik penduduk, serta menganlisis kekeritisan air domestik di Kabupaten Malang. Tahapan penelitian yang dilakukan yakni: 1) Mengumpulkan data yang digunakan dalam penelitian; 2) Melakukan analisis ketersediaan air meteorologis; 3) Melakukan analisis kebutuhan air domestic; 4) Melakukan analisis tingkat kekritisan air; 5) Melakukan survei lapangan; 6) Melakukan pemetaan. Hasil penelitian menunjukkan bahwa ketersediaan air meteorologis tertinggi yaitu di Kecamatan Sumbermanjing Wetan dan ketersediaan air meteorologis terendah yaitu di Kecamatan Lawang, Sedangkan untuk kebutuhan air domestik tertinggi yaitu di Kecamatan Lawang dan kebutuhan air domestik terendah yaitu di Kecamatan Pagak. Wilayah dengan tingkat kekritisan air pada kategori sangat kritis yaitu di Kecamatan Lawang dan Kecamatan Singosari dengan, sedangkan wilayah tingkat kekritisan air pada ketegori tidak kritis yaitu di Kecamatan Donomulyo.
\end{abstract}

Kata kunci: air meteorologis, air domestik, kekritisan air

\section{Pendahuluan}

Kabupaten Malang adalah sebuah kabupaten yang terletak di Provinsi Jawa Timur. Kabupaten Malang terbagi menjadi 33 kecamatan, dengan luas wilayahnya yaitu 2977,05 km². Jumlah penduduk di Kabupaten Malang setiap tahunnya selalu mengalami peningkatan. Pada tahun 2010 jumlah penduduk di kabupaten Malang sebesar 2.451.997 jiwa, dan pada tahun 2017 sebesar 2.576 .596 jiwa. Dalam kurun waktu 8 tahun peningkatan jumlah penduduk di Kabupaten Malang sebesar 124.599 jiwa (BPS, 2017).

Air merupakan komponen yang penting bagi kehidupan makhluk hidup di muka bumi dan tidak dapat terlepas dari kebutuhan air. Air adalah kebutuhan utama dalam proses kehidupan di bumi sehingga tidak ada kehidupan seandainya jika tidak ada air di bumi. Air adalah unsur yang sulit untuk dipisahkan dari kehidupan manusia.

Pentingnya peranan air bagi kehidupan mahkluk di permukaan bumi, sangat diperlukan adanya sumber air yang dapat menyediakan air baik dari segi kuantitas dan kualitasnya. Di Indonesia umumnya sumber air bersih berasal dari air permukaan, air tanah, dan air hujan. Penggunaan air oleh manusia untuk berbagai kepentingan menyebabkan perkembangan pengelolaan air baik air permukaan maupun air tanah menjadi sangat pesat terjadi. Hal ini disebabkan karena manusia sadar akan pentingnya air bagi kehidupan (Herlambang, 2013) 
Perkembangan pada suatu daerah tertentu akan menyebabkan air yang dibutuhkan terus meningkat seiring dengan bertambahnya jumlah penduduk. Jumlah penduduk yang setiap tahun terus mengalami peningkatan dan persebaran penduduk yang tidak merata akan berpengaruh terhadap peningkatan kebutuhan air. Perubahan alih fungsi lahan akibat dari peningkatan jumlah penduduk mengakibatkan beberapa sumberdaya menjadi langka, salah satunya adalah sumberdaya air. Perubahan penggunaan lahan tersebut menyebabkan jumlah air berkurang dan masyarakat terpaksa membeli air dari daerah lain (Alkhairaat, 2010).

Persebaran curah hujan yang tidak merata akibat dari keragaman kondisi fisiografis Kabupaten Malang juga menyebabkan ketersediaan air disetiap wilayah berbeda. Hujan merupakan fenomena alam yang berperan sebagai pengendali siklus hidrologi, air hujan berperan sebagai penyedia utama pemenuhan kebutuhan air (Sandy, 2012).

Permasalahan pada umumnya terjadi karena adanya ketidakseimbangan antara ketersediaan dan kebutuhan air. Upaya pengkajian komponen ketersediaan dan kebutuhan air diperlukan untuk mencapai keseimbangan antara kebutuhan air domestik dan ketersediaan air meteorologis di masa yang akan datang. Ketersediaan dan kebutuhan air merupakan upaya analisis sumberdaya air untuk meminimalisir terjadinya kelangkaan air (Sandy, 2012).

Kebutuhan air untuk setiap daerah di Kabupaten Malang berbeda karena masing - masing wilayah memiliki karakteristik fisik dan sosial yang berbeda. Kebutuhan air berdasarkan penuggunaannya dapat dibedakan menjadi kebutuhan air irigasi, kebutuhan air domestik, dan kebutuhan air non domestik (Susilah, 2013).

Apabila tidak ada keseimbangan antara kebutuhan air domestik dan ketersediaan air meteorlogis di suatu wilayah, maka akan menyebabkan kondisi yang disebut kekritisan air domestik. Penelitian ini dilakuakan di tujuh kecamatan yang ada di Kabupaten Malang yaitu, Kecamatan Kalipare, Kecamatan Donomulyo, Kecamatan Pagak, Kecamatan Sumbermanjing Wetan, Kecamatan Jabung, Kecamatan Singosari, dan Kecamatan Lawang. Tujuan penelitian ini adalah menganalisis ketersediaan air meteorologis dan mengalisis kebutuhan air domestik penduduk, serta menganlisis kekeritisan air domestik di Kabupaten Malang.

\section{Metoda Penelitian}

Penelitian ini menggunakan pendekatan kuantitatif dan menggunakan metode deskriptif. Tahapan penelitian yang dilakukan sebagai berikut:

1. Pengumpulan data yang digunakan untuk penelitian, berupa data curah hujan perkecamatan yang ada di Kabupaten Malang tahun 2006 - 2015. Data jumlah penduduk ditujuh kecamatan yang ada di Kabupaten Malang tahun 2006-2015.

2. Melakukan analisis ketersediaan air meteorologis dengan rumus:

Ket:

$$
V=(P 1 \times A 1)+(P 2 \times A 2)+(P 3 \times A 3)
$$

$\mathrm{V}=$ Volume ketersediaan air $\left(\right.$ liter $\left./ \mathrm{dm}^{3}\right)$

$\mathrm{P} 1, \mathrm{P} 2, \mathrm{P} 3=$ Curah Hujan $(\mathrm{mm})$

$\mathrm{A} 1, \mathrm{~A} 2, \mathrm{~A} 3=$ Luas wilayah $\left(\mathrm{km}^{2}\right)$

3. Melakukan analisis kebutuhan air domestik penduduk dengan rumus:

$$
K d=n d \sum P d
$$

Ket:

$\mathrm{Kd}=$ Kebutuhan air domestik (liter)

$\mathrm{N} \quad=$ Jumlah hari perbulan

$\mathrm{d}=$ Asumsi kebutuhan air (100 liter)

$\sum \mathrm{Pd} \quad=$ Jumlah penduduk 
4. Melakukan analisis tingkat kekritisan air dengan rumus:

$$
\begin{array}{lll} 
& \multicolumn{1}{c}{I K=} & \text { Kebutuhan Air } \\
\cline { 1 - 2 } \text { Kelas kritisan } & \text { Keterangan } & \\
\hline<50 \% & \text { Tidak Kritis } & \\
50-75 \% & \text { Agak Kritis } & \\
76-100 \% & \text { Kritis } & \\
>100 \% & \text { Sangat Kritis } & \\
\text { Sumber: Direktorat Bina Progrem dalam Martopo (1991) }
\end{array}
$$

5. Melakukan survey lapangan untuk mencocokkan hasil analisis dengan kondisi dilapangan.

6. Melakuakan pemetaan dengan menggunakan aplikasi ArcMap 10.2

\section{Hasil}

\section{Ketersediaan Air Meteorologis}

Ketersediaan air secara meteorologis diperoleh berdasarkan perhitungan rata-rata curah hujan dikalikan dengan luas wilayah.

Tabel 1. Luas Wilayah Penelitian

\begin{tabular}{ll}
\hline Kecamatan & Luas(km2) \\
\hline Kalipare & 10539 \\
Donomulyo & 19260 \\
Pagak & 9008 \\
Sumbermajing Wetan & 23449 \\
Jabung & 13589 \\
Singosari & 11851 \\
Lawang & 6823 \\
\hline
\end{tabular}

Sumber: malangkab.bps.go.id 2015

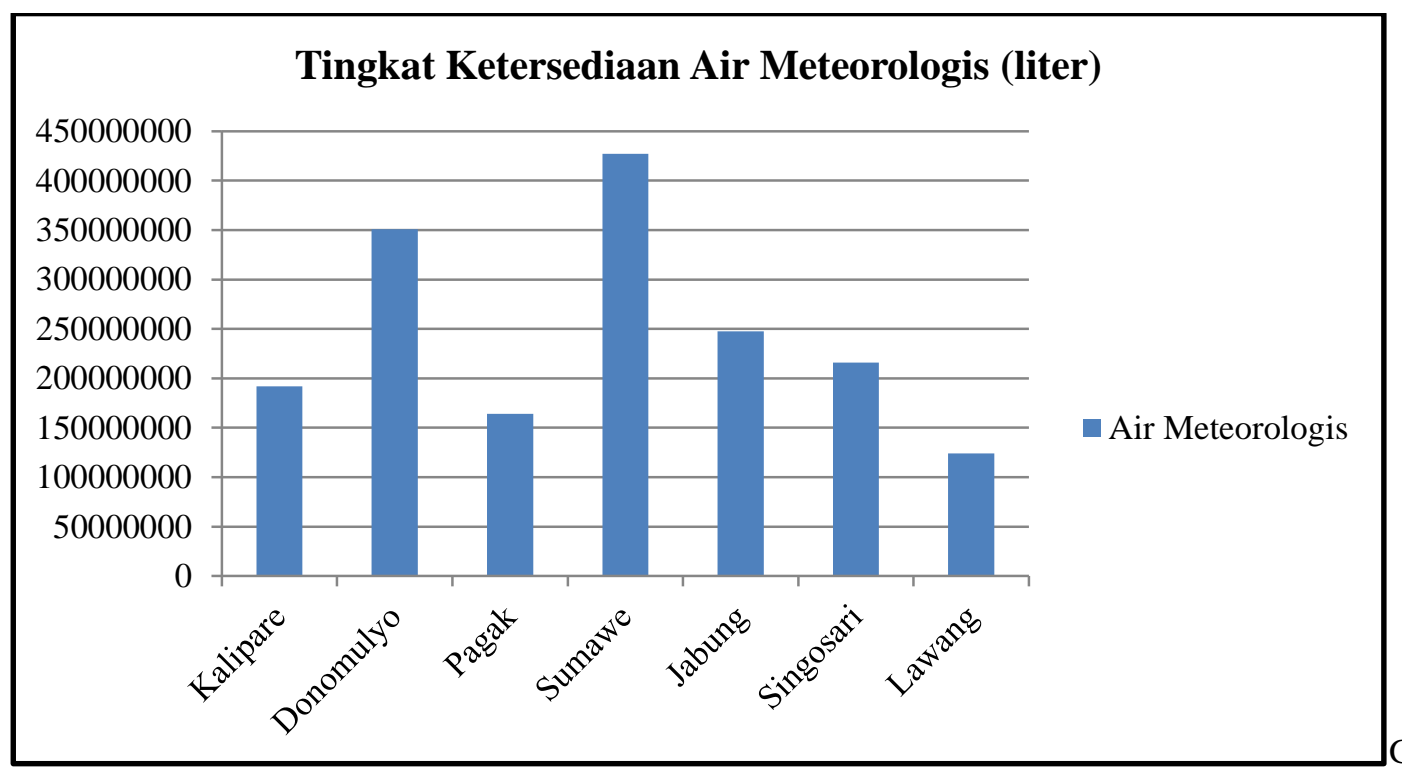

Diagram batang tingkat ketersediaan air meteorologis

Gambar 1.

Berdasarkan hasil penelitian menunjukkan tingkat ketersediaan air meteorologis pada Kecamatan Kalipare sebesar 191.915.190 juta liter, Kecamatan Donomulyo memiliki tingkat 
ketersediaan air sebesar 350.724.600 liter, Kecamatan Pagak memiliki tingkat ketersediaan air sebesar 164.035.680 liter, Kecamatan Sumbermanjing Wetan memiliki tingkat ketersediaan air sebesar 427.006.290 liter, Kecamatan Jabung memiliki tingkat ketersediaan air sebesar 247.455.690 liter, Kecamatan Singosari memiliki tingkat ketersediaan air sebesar 215.806.710 liter, dan Kecamatan Lawang memiliki tingkat ketersediaan air sebesar 124.246.830 liter.

\section{Kebutuhan Air Domestik}

Kebutuhan air domestik merupakan kebutuhan air yang digunakan untuk memenuhi keperluan sehari-hari oleh masyarakat. Kebutuhan air domestik diperoleh berdasarkan jumlah hari dalam satu bulan dikalikan dengan asumsi kebutuhan air (100/liter) dan dikalikan dengan jumlah penduduk disetiap kecamatan.

Tabel 2. Jumlah Penduduk Penlitian

\begin{tabular}{ll}
\hline Kecamatan & Jumlah Penduduk (jiwa) \\
\hline Kalipare & 607088 \\
\hline Donomulyo & 571462 \\
\hline Pagak & 450271 \\
\hline Sumbermanjing & 892935 \\
\hline Jabung & 710162 \\
\hline Singosari & 1594128 \\
\hline Lawang & 1010286 \\
\hline Sumber: malangkab.bps.go.id 2015
\end{tabular}

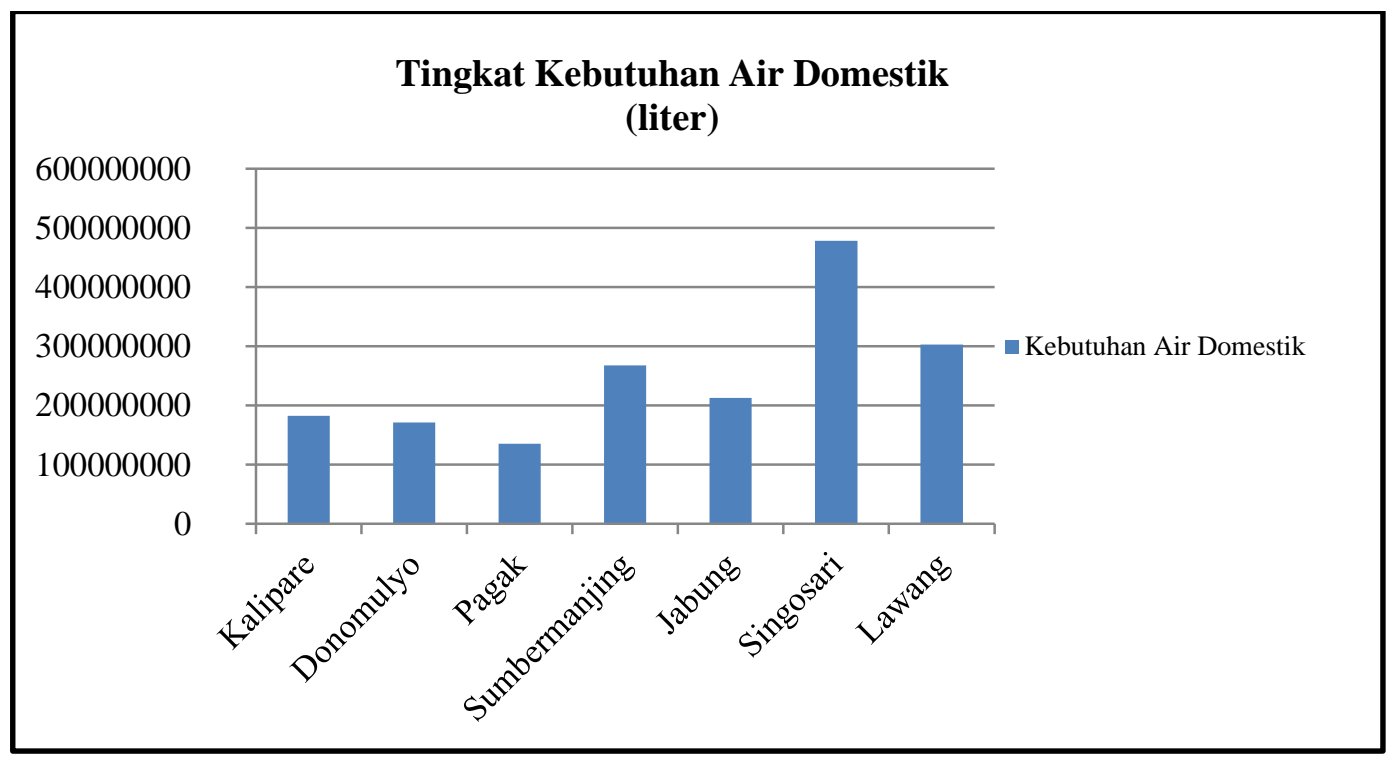

Gambar 2. Diagram batang tingkat kebutuhan air domestik

Berdasarkan gambar diagram batang hasil perhitungan maka tingkat kebutuhan air domestik pada Kecamatan Kalipare sebesar 182.126.400 liter/bulan, Kecamatan Donomulyo tingkat kebutuhan air domestiknya sebesar 171.438.600 liter/bulan, Kecamatan Pagak tingkat kebutuhan air domestiknya sebesar 135.081.300 liter/bulan, Kecamatan Sumawe kebutuhan air domestiknya sebesar 267.880.500 liter/bulan, Kecamatan Jabung kebutuhan air domestiknya sebesar 213.048.600 liter/bulan, Kecamatan Singosari kebutuhan air domestiknya sebesar 
478.238.400 liter/bulan, Kecamatan Lawang kebutuhan air domestiknya sebesar 303.085.800 liter/bulan.

\section{Tingkat kekritisan air}

Sebaran kekritisan air di peroleh berdasarkan perhitungan ketersediaan air meteorologis dan kebutuhan air domestic. Keadaan kritis adalah apabila kebutuhan air domestik melebihi 75\% dari ketersediaan air (Direktorat Bina Progrem dalam Martopo, 1991). Tingkat kekritisan air dapat dihitung menggunakan hasil kebutuhan air domestik dibagi dengan ketersediaan air meteorlogis dikalikan $100 \%$.

Tabel 1. Tingkat kekritisan air di Kabupaten Malang

\begin{tabular}{lll}
\hline Kecamatan & Nilai Kekritisan & Kategori \\
\hline Kalipare & $94 \%$ & Kritis \\
Donomulyo & $48 \%$ & Tidak Kritis \\
Pagak & $82 \%$ & Kritis \\
Sumawe & $62 \%$ & Agak Kritis \\
Jabung & $86 \%$ & Kritis \\
Singosari & $221 \%$ & Sangat Kritis \\
Lawang & $243 \%$ & Sangat Kritis \\
\hline
\end{tabular}

Sumber: Hasil analisis

Berdasarkan tabel 1. tingkat kekritisan air di Kecamatan Kalipare adalah 94\% berada pada tingkat kritis, di Kecamatan Donomulyo $48 \%$ berada pada tingkat tidak kritis, di Kecamatan Pagak $82 \%$ berada pada tingkat kritis, di Kecamatan Sumbermanjing Wetan 62\% berada pada tingkat agak kritis, di Kecamatan Jabung $86 \%$ berada pada kritis, di Kecamatan Singosari $221 \%$ berada pada tingkat sangat kritis dan di Kecamatan Lawang $243 \%$ berada pada tingkat sangat kritis.

\section{Pembahasan}

Berdasarkan hasil analisis data diketahui bahwa ketersediaan air meteorologis pada tujuh kecamatan yang ada di Kabupaten Malang memiliki tingkat ketersediaan air meteorologis yang berbeda. Ketersediaan air meteorologis merupakan ketersediaan air yang berasal dari air hujan (Suripin, 2011: 27). Ketersediaan air meteorologis diperoleh dari perhitungan rata-rata curah hujan dengan metode poligon thiessen dikalikan dengan luas wilayah masing-masing kecamatan.

Ketersediaan air meteorologis paling tinggi yaitu di Kecamatan Sumbermanjing Wetan, sedangkan ketersediaan air meteorologis paling rendah yaitu di Kecamatan Lawang. Perbedaan ketersediaan air meteorologis pada setiap daerah berbeda karena sesuai dengan tingkat curah hujan dan luas wilayahnya. Hal tersebut sesuai dengan yang dimaksudkan (Muliranti, 2010) bahwa semakin tinggi tingkat curah hujan dan semakin luas wilayahnya maka ketersediaan air meteorologisnya akan besar begitupun sebaliknya.

Berdasarkan hasil analisis data diketahui bahwa ketersediaan air meteorologis pada tujuh kecamatan yang ada di Kabupaten Malang memiliki tingkat ketersediaan air meteorologis yang berbeda. Ketersediaan air meteorologis merupakan ketersediaan air yang berasal dari air hujan (Suripin, 2011: 27). Ketersediaan air meteorologis diperoleh dari perhitungan rata-rata curah hujan dengan metode poligon thiessen dikalikan dengan luas wilayah masing-masing kecamatan. 


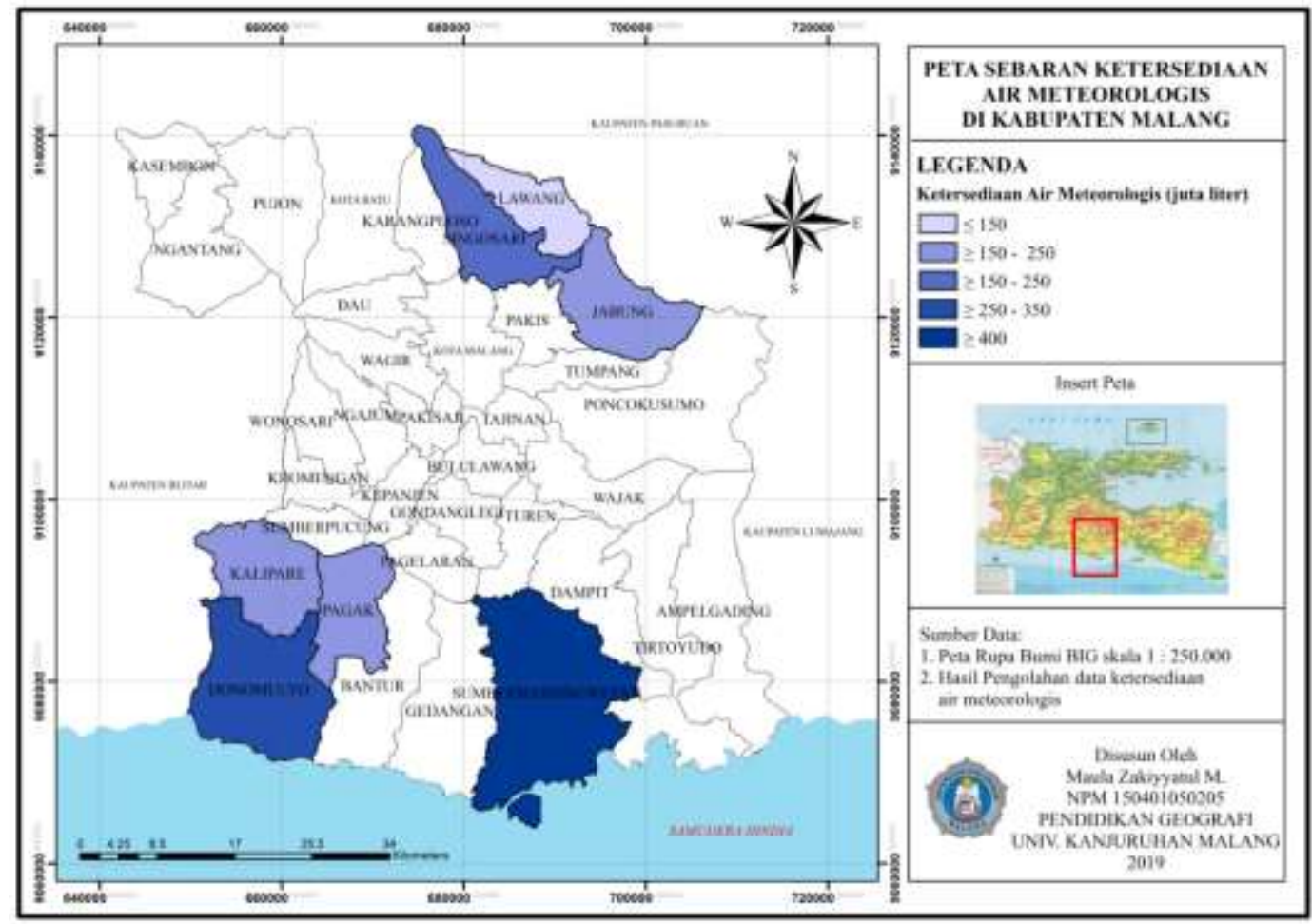

Gambar 3. Peta Sebaran Ketersediaan air Meteorologis

Ketersediaan air meteorologis paling tinggi yaitu di Kecamatan Sumbermanjing Wetan, sedangkan ketersediaan air meteorologis paling rendah yaitu di Kecamatan Lawang. Perbedaan ketersediaan air meteorologis pada setiap daerah berbeda karena sesuai dengan tingkat curah hujan dan luas wilayahnya. Hal tersebut sesuai dengan yang dimaksudkan (Muliranti, 2010) bahwa semakin tinggi tingkat curah hujan dan semakin luas wilayahnya maka ketersediaan air meteorologisnya akan besar begitupun sebaliknya.

Sebaran hujan yang tidak merata pada setiap daerah yang ada di Kabupaten Malang akan berpengaruh terhadap ketersediaan air meteorologisnya. Hal tersebut sesuai dengan pendapat Hadisusanto (2010: 20) bahwa persebaran curah hujan yang tidak merata akan mempengaruhi jumlah ketersediaan air meteorologis yang berbeda antara satu tempat dengan tempat lainnya.

Berdasarkan hasil analisis perhitungan kebutuhan air domestik di tujuh kecamatan yang ada di Kabupaten Malang memiliki tingkat kebutuhan air domestik yang berbeda. Kebutuhan air domestik merupakan kebutuhan air yang digunakan pada tempat-tempat hunian untuk memenuhi keperluan hidup sehari-hari seperti memasak, mencuci, dan keperluan rumah tangga lainnya. Kebutuhan air domestik diperoleh berdasarkan perhitungan jumlah penduduk dikalikan dengan jumlah hari dalam sebulan dan asumsi kebutuhan air. Kebutuhan air domestik dihitung berdasarkan jumlah penduduk, kebutuhan air per kapita dan proyeksi waktu air yang digunakan (Yulistiyanto dan Kironoto, 2010)

Kebutuhan air domestik paling tinggi yaitu di Kecamatan Singosari karena jumlah penduduk di Kecamatan Singosari sangat besar sehingga masyarakat membutuhkan banyak air untuk keperluan sehari-hari. Sedangkan untuk kebutuhan air domestik paling rendah yaitu di Kecamatan Pagak karena jumlah penduduk di kecamatan tersebut hanya sekitar 450.271 jiwa. Perbedaan jumlah kebutuhan air domestik dilihat dari banyaknya jumlah penduduk yang tinggal di wilayah tersebut. Semakin banyak jumlah penduduk pada suatu daerah maka tingkat kebutuhan air domestiknya akan tinggi, dan semakin sedikit jumlah penduduk pada suatu daerah maka tingkat kebutuhan air domestiknya akan semakin rendah. 


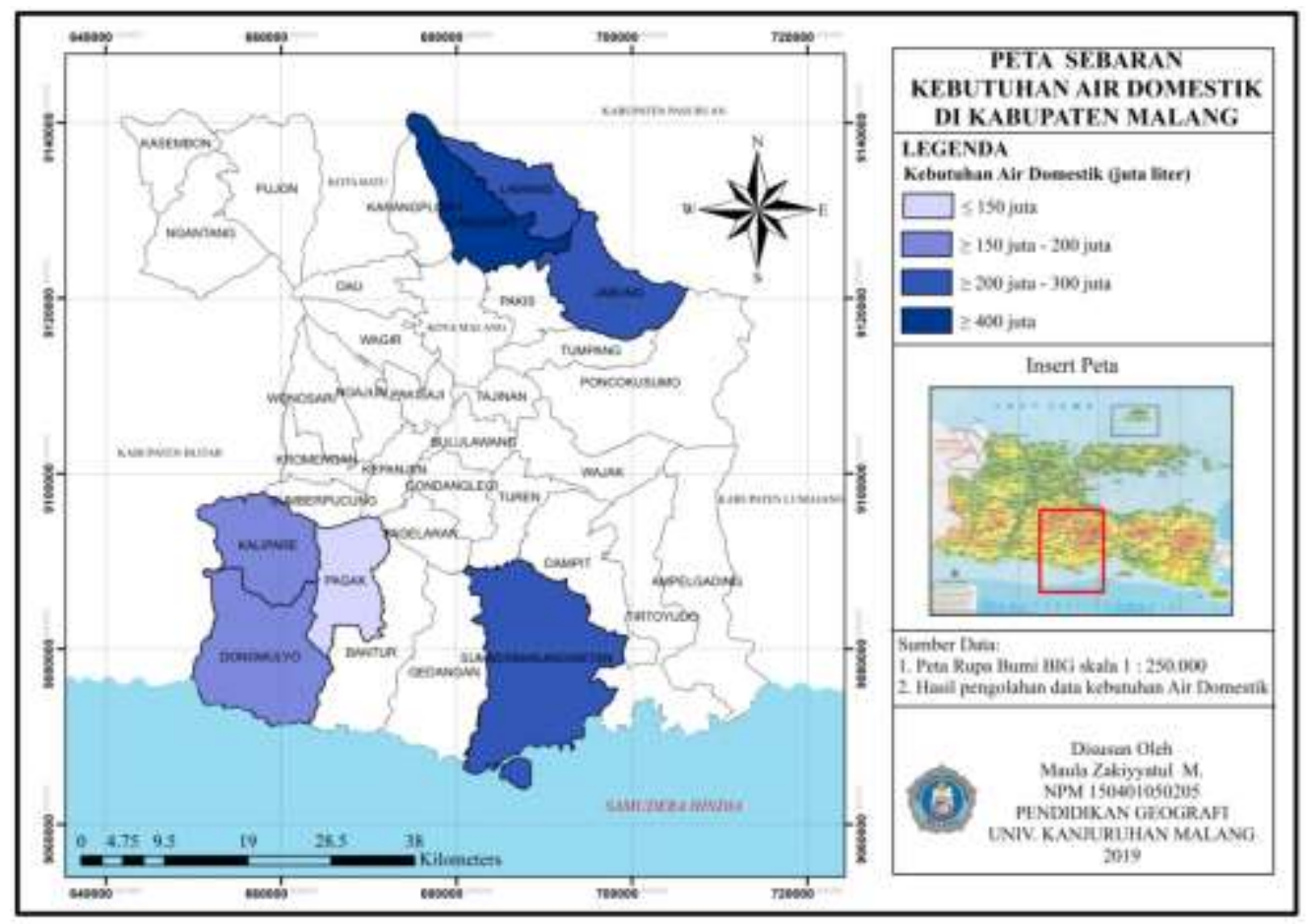

Gambar 4. Peta Sebaran Kebutuhan air domestic

Hasil analisis tingkat kekritisan air pada wilayah penelitian di Kabupaten Malang menunjukkan bahwa, tingkat kekritian air paling tinggi kategori sangat kritis yaitu di Kecamatan Lawang sebesar 243\% dan Kecamatan Singosari sebesar 221\%, sedangkan tingkat kekritisan paling rendah kategori tidak kritis yaitu di Kecamatan Donomulyo dengan hasil perhitungan sebesar 48\%. Tingkat kategori kritis yaitu di Kecamatan Pagak dan Kecamatan Jabung, ketogori agak kritis yaitu di Kecamatan Sumbermanjing Wetan. Hal ini sesuai dimana keadaan kritis terjadi apabila kebutuhan air lebih dari 75\% dari ketersediaan airnya (Direktorat Bina Program dalam Martopo 1991).

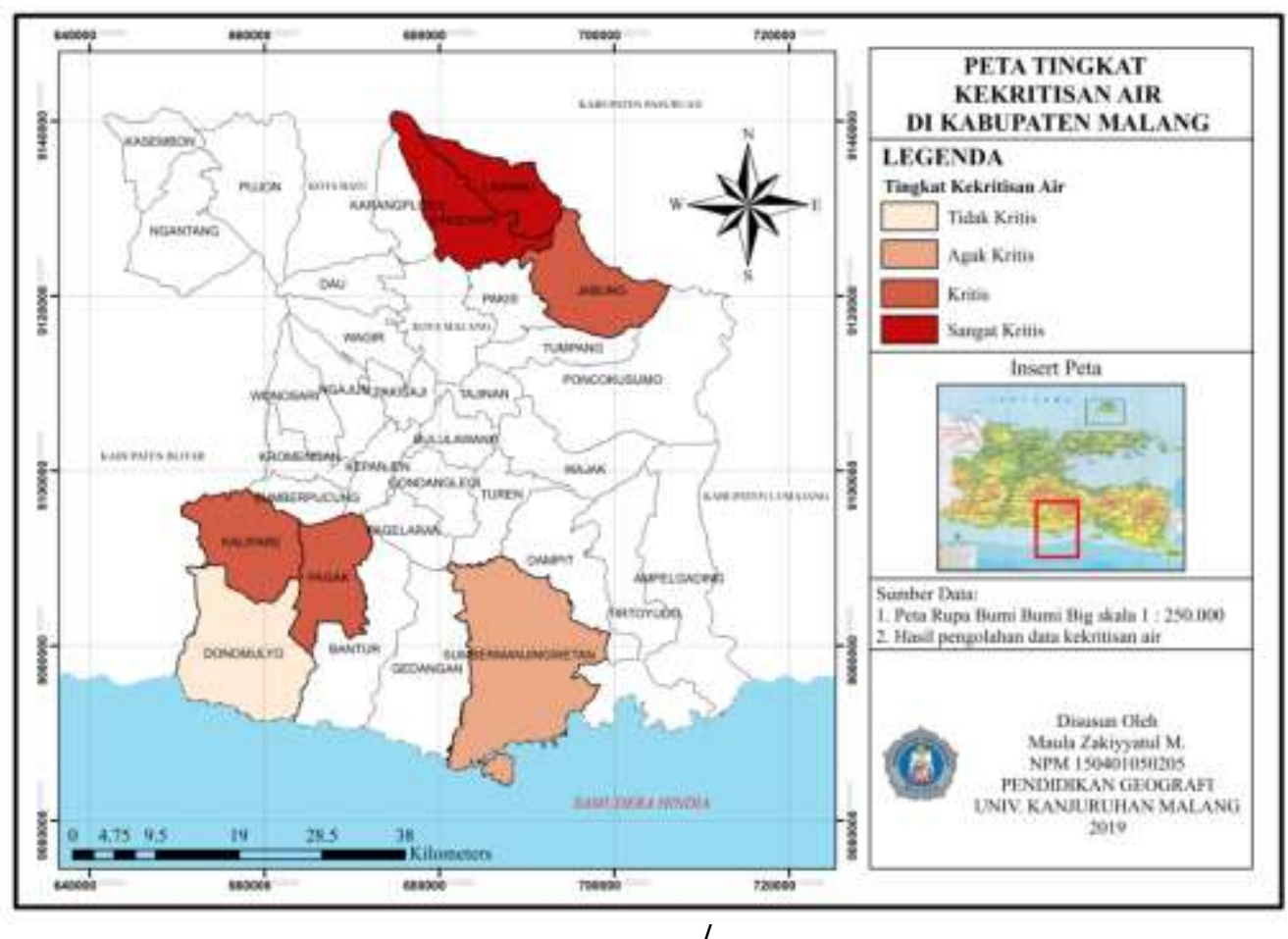


Wilayah Kecamatan Singosari dan Kecamatan Lawang yang berada pada kategori tingkat kekritisan sangat kritis dipengaruhi oleh ketersediaan air yang sedikit karena intensitas curah hujan pada wilayah tersebut sangat rendah, sedangkan jumlah penduduk pada dua kecamatan tersebut sangat tinggi yang mengakibatkan kebutuhan air domestiknya tinggi. Pada Kecamatan Jabung, Kecamatan Kalipare, dan Kecamatan Pagak yang berada pada kategori kritis dipengaruhi oleh ketersediaan air meteorologis yang cukup namun masih belum bisa memenuhi untuk kebutuhan air domestiknya. Sedangkan pada Kecamatan Sumbermanjing Wetan yang berada pada kategori agak kritis dipengaruhi oleh ketersediaan air meteorologis yang besar karena intensitas curah hujannya yang tinggi, hal ini dipengaruhi oleh luas wilayah pada kecamatan tersebut. Namun pada Kecamatan Sumbermanjing Wetan merupakan kawasan karst yang tingkat porositas dan permeabilitasnya tinggi mengakibatkan wilayah tersebut masih sulit untuk memperoleh air bersih.

Faktor terjadinya kekritisan air domestik apabila pada daerah dengan jumlah penduduk yang tinggi dan intensitas curah hujan hujan yang rendah pada wilayah tersebut. Daerah yang memiliki kepadatan penduduk yang besar berarti kemampuan setiap orang untuk memenuhi kebutuhan air sehari-harinya akan semakin sulit, terlebih lagi jika curah hujan yang turun didaerah tersebut jumlahnya sedikit. Tidak ada keseimbangan antara ketersediaan air meteorologis dan kebutuhan air domestik mengakibatkan kekritisan air domestic itu terjadi (Muliranti, 2013).

Tingkat kekritisan air pada setiap daerah berbeda karena dipengaruhi oleh ketersediaan dan kebutuhan akan airnya. Apabila ketersediaan air meteorologisnya melimpah dan kebutuhan akan air domestiknya sedikit maka tidak akan terjadi kekritisan air. Namun jika ketersediaan air meteorologisnya sedikit dan kebutuhan air domestiknya tinggi maka kekritisan air itu akan terjadi. Hal ini sesuai bahwa tidak adanya keseimbangan antara kebutuhan air penduduk yang terus meningkat dengan ketersediaan air maka akan memicu tingkat kekritisan air (Hamdani, 2017). Sebaran ketersediaan dan kebutuhan air penting untuk diketahui agar tingkat kekritisan air yang terjadi secara keruangan tidak terus meningkat.

\section{Kesimpulan}

Wilayah dengan tingkat kekritisan air pada kategori sangat kritis yaitu di Kecamatan Lawang dan Kecamatan Singosari dengan, wilayah dengan tingkat kekritisan air pada kategori kritis yaitu di Kecamatan Kalipare, Kecamatan Pagak, Kecamatan Jabung, wilayah dengan kategori agak kritis yaitu di Kecamatan Sumbermanjing Wetan, dan wilayah tingkat kekritisan air pada ketegori tidak kritis yaitu di Kecamatan Donomulyo. Pemerintah Daerah perlu melakukan upaya untuk mengurangi resiko terjadi kekritisan air domestik, dengan cara penyediaan sumber air khusunya untuk wilayah yang mengalami kekritisan air.

\section{Daftar Rujukan}

Alkhairaat, 2010. Analisa Perubahan penggunaan lahan di Kota Palu Provinsi Sulawesi Tengah. (Online), Jurnal Teknik Vol. 30 No. 1, ISSN 0852-1697.

BPS. 2017. Kabupaten Malang dalam angka 2017. (Online), https://malangkab.bps.go.id/ Di akses 1 September 2018 Hadisusanto, A. 2010. Ketersediaan Air Bersih dan Perubahan Iklim: Studi Krisis Air Di Kedungkarang Kabupaten Demak. Junal Teknik PWK, Volume 3 No 22010. 
Hadisusanto, A. 2010. Ketersediaan Air Bersih dan Perubahan Iklim: Studi Krisis Air Di Kedungkarang Kabupaten Demak. Junal Teknik PWK, Volume 3 No 2010.

Hamdani, A.F. dan Susanti, N.E., 2017. Analisis Kajian Meteorologis Ketersediaan Dan Tingkat Kekritisan Air Domestik Desa Girimoyo, Kecamatan Karangploso, Kabupaten Malang. Prosiding Seminar Nasional Penelitian dan Pengabdian Kepada Masyarakat. Malang: Universitas Kanjuruhan Malang.

Martopo, S. 2011. Keseimbangan Ketersediaan Air di Pulau Bali. Laporan Penelitian. Fakultas Geografi UGM, Yogyakarta.

Muliranti, S. dan Hadi M.P., 2013. Kajian Ketersediaan Air Meteorologis Untuk Pemenuhan Kebutuhan Air Domestik di Provinsi Jawa Tengah dan DIY.

Sandy, I.M. 2012. Iklim regional Indonesia. Jurusan Geografi Fakultas Mipa Universitas Indonesia, Jakarta.

Susilah, S. 2013. Studi Analisa Kapasitas Debit Terhadap Kebutuhan Air Bersih Proyeksi Tahun 2009 - 2014 Pada IPA Bantuan Oxfam (PDAM Tirta Mon Pase) Kabupaten Aceh Utara. (Online) Teras Jurnal, Vol.3 No.3 Hal.23-28. 